\title{
Projected effects of temperature changes on the Italian Western Tauri glaciers (Eastern Alps)
}

\author{
ROSSANA SERANDREI-BARBERO, ${ }^{1}$ SANDRA DONNICI, ${ }^{2}$ @ STEFANO ZECCHETTO ${ }^{3}$ \\ ${ }^{1}$ Formerly CNR - National Research Council of Italy, ISMAR - Marine Sciences Institute in Venice, Castello 2737/F, \\ 30122 Venice, Italy and Comitato Glaciologico Italiano, Torino, Italy \\ ${ }^{2}$ CNR - National Research Council of Italy, ISMAR - Marine Sciences Institute in Venice, Arsenale T104-Castello 2737/F, \\ 30122 Venice, Italy \\ ${ }^{3}$ CNR - National Research Council of Italy, ISAC - Institute of Atmospheric Sciences and Climate, Corso Stati Uniti 4, \\ 35127 Padova, Italy \\ Correspondence: Sandra Donnici <sandra.donnici@cnr.it>
}

\begin{abstract}
A linear model was used to investigate the behaviour of the Italian Western Tauri glaciers as a result of temperature changes projected for the $21 \mathrm{st}$ century. The model estimates the temperature variations once the glacier snout length variations are known and vice versa: it estimates the glacier snout length variations once the air temperature variations are known or predicted. The $\mathbf{4 6}$ glaciers of the Italian Western Tauri, $35(76 \%)$ of which have areas smaller than $0.5 \mathrm{~km}^{2}$ and only $7(15 \%)$ larger than $\mathbf{1} \mathbf{k m}^{2}$, are mostly mountain type glaciers and only three are presently valley glaciers. The model has been forced by the air temperature projections of the A1B emission scenario, which indicates an increase in temperature of $2.7^{\circ} \mathrm{C}$ from 2015 to 2100 . The results show a shortening of more than $35 \%$ for mountain glaciers by $\mathbf{2 1 0 0}$ with a surface loss of more than $\mathbf{6 0} \%$ and smaller reductions for valley glaciers. The consequent fragmentation into smaller units would lead to the extinction of $95 \%$ of the existing glaciers by the end of the century, possibly leaving only the valley glaciers surviving.
\end{abstract}

Keywords: climate change, glacier fluctuations, glacier modelling, mountain glaciers

\section{INTRODUCTION}

On glaciers, the annual variations of the mass-balance result in snout fluctuations with a time lag that depends on both their morphological characteristics and the meteorological forcing. The glacier length changes expressed by snout fluctuations can therefore be considered a proxy of the mass balance (Oerlemans, 1994; Hoelzle and others, 2003).

Field measurements of glacier length variations have been carried out in the European Alps since the late 19th century (Citterio and others, 2007; Zemp and others, 2015; Fischer and others, 2018); they are available in web archives such as the World Glacier Monitoring Service (http://wgms.ch/) (WGMS, 2015). The major part of the available field data refers to glaciers of large or medium size, while very small glaciers $\left(<0.5 \mathrm{~km}^{2}\right)$, representing $\sim 80 \%$ of the total number in temperate mountains (Huss and Fischer, 2016), are ignored for both their small size and inaccessible location, possibly introducing a bias in the quantification of the current trend and of the expected glacier changes.

In the 1980s, on the Italian side of the Alps, 1397 glaciers with a total area of $608 \mathrm{~km}^{2}$ were identified on the basis of data collected for the World Glacier Inventory (SerandreiBarbero and Zanon, 1993); more recently, only 903 glaciers have been catalogued, $84 \%$ of them with areas $<0.5 \mathrm{~km}^{2}$ and $9.4 \%>1 \mathrm{~km}^{2}$ (Smiraglia and Diolaiuti, 2015). In both glacier inventories, the areas were obtained from aerial photographs integrated with ground surveys. Despite their small size, the large fraction of small glaciers implies that they affect the Alpine landscape, its biodiversity and geodiversity, and the land use in the full basin, trasforming the nival and pluvial regime into a mixed runoff system. The possibility of their extinction due to ongoing climate change is therefore of great interest. The largest part of these glaciers belongs to the mountain type (mainly cirque, niche and slope glaciers). They differ from the valley glaciers by the absence of the valley tongue (Cogley and others, 2011).

According to Roe and O'Neal (2009) and Oerlemans (2011), a first-order linear differential equation (hereafter the linear model) linking the glacier snout to air temperature fluctuations is the simplest approach to reproduce climatic changes such as those observed in the Alps. Using the length fluctuations and the concept of climate sensitivity, i.e., the decrease in equilibrium glacier length per degree temperature increase, Oerlemans (2005) re-constructed the temperature variations in recent centuries from numerous worldwide glaciers. The linear model developed by Leclercq and Oerlemans (2012) has been applied for the first time to three small valley glaciers located on the Italian side of the Alps (Zecchetto and others, 2017), reproducing the temperature variations for the period 1929-2011.

The aim of this work is to apply this model to both the valley and the mountain type glaciers of the Italian Western Tauri Alps to obtain a first estimate of their retreat during the 21 st century. All the mountain glaciers, even those most widespread with areas smaller than $1 \mathrm{~km}^{2}$, were taken into account. Glacier length variations observed on a group of nine glaciers were used to determine the underlying temperature forcing, which was in good agreement with regional temperature records. The temperature projections of the A1B emission scenario (Nakićenovic and others, 2000) were then used to force the model length changes of the glaciers measured to date and of unmeasured glaciers. In this work, we assume that the area of interest is subjected to the same temperatures and precipitation in 


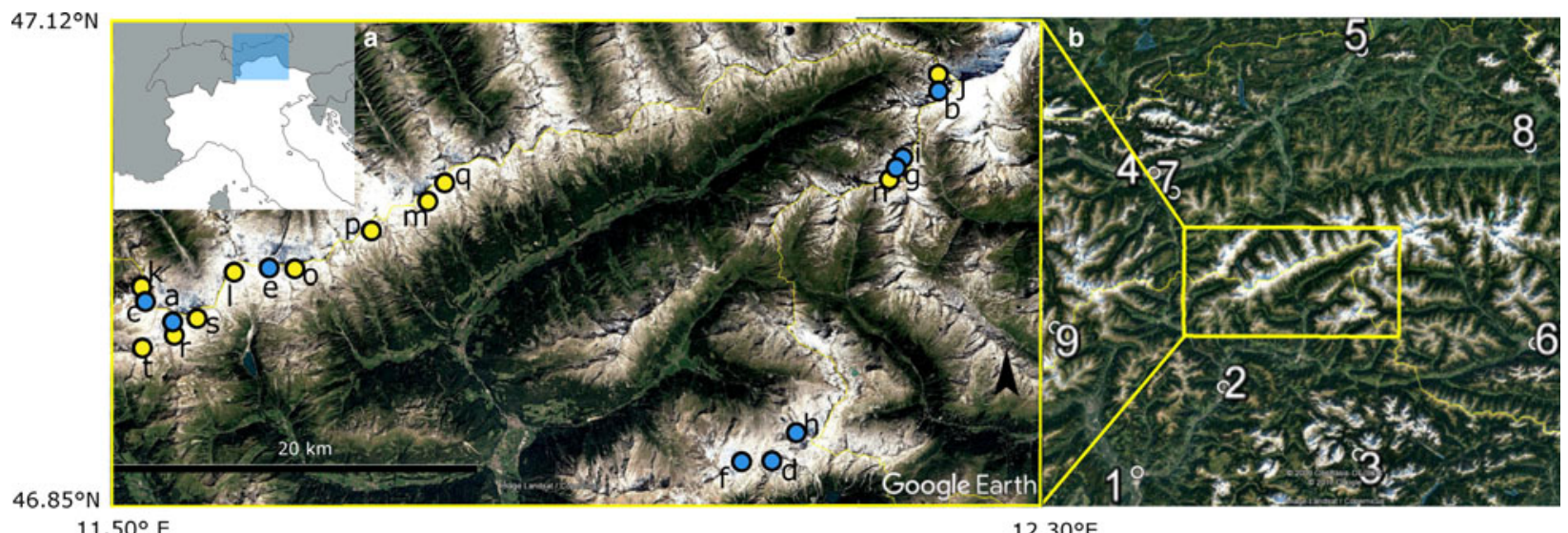

Fig. 1. The Italian Western Tauri (Eastern Alps). Panel a: locations of the studied glaciers (blue dots, a-i in Table 1 ; yellow dots, $j-t$ in Table 2). Panel b: locations of the climatic stations 1 Bozen/Bolzano, 2 Brixen/Bressanone, 3 Cortina d'Ampezzo, 4 Innsbruck University, 5 Kufstein, 6 Lienz, 7 Patscherkofel, 8 Zell am See and 9 Obergurgl-Vent.

order to achieve a first regional assessment of the ongoing glacial shrinkage despite the low number of monitored glaciers.

\section{THE DATA}

\subsection{The Italian Western Tauri glaciers}

To achieve a regional assessment, all the glaciers belonging to the Italian Western Tauri (hereafter the Western Tauri glaciers), a sector of the Eastern Alps, have been considered. In 1962, 63 glaciers were inventoried (Consiglio Nazionale delle Ricerche - Comitato Glaciologico Italiano, 19591962), and only 46 of them existed in 2008 (Smiraglia and Diolaiuti, 2015). Among these 46 glaciers, 35 (76\%) have areas $<0.5 \mathrm{~km}^{2}$ and seven (15\%) have areas $>1 \mathrm{~km}^{2}$; nine glaciers (Fig. 1, panel a) were continuously monitored with snout measurements starting from the early 1980s (WGMS, 2015). The snout measurements are the differences in the locations of the glacier front from a fixed reference point at different time intervals, providing a record of the glacier's length changes. These glaciers (hereafter the measured glaciers) belong to both the valley and mountain types according to the World Glacier Inventory classification; in 1982, they had areas between 2.6 and $0.4 \mathrm{~km}^{2}$ and lengths between 3700 and $1200 \mathrm{~m}$. Their area reductions in the period 1982-2008 are between 25 and 55\% (0.17-1.1 $\left.\mathrm{km}^{2}\right)$ with a mean loss of $39 \%\left(0.6 \mathrm{~km}^{2}\right)$; their length reductions between 1982 and 2015 range from 10 to 34\% (225$767 \mathrm{~m}$ ) with an average of $21 \%(462 \mathrm{~m})$ (Table 1).

Among the glaciers without any front variation measurement (hereafter the unmeasured glaciers), all belonging to the mountain glacier type, only those with an area decrease not exceeding 50\% between 1982 and 2008, have been selected. This threshold is an a priori choice to respect the condition for the application of the linear model, i.e., glacier length variations much smaller than mean length (see Eqn (5)). As a consequence of this threshold, 11 glaciers have been considered (Table 2; Fig. 1, panel a). In 1982, the lengths of these 11 glaciers ranged between 1800 and $700 \mathrm{~m}$ and their areas between 1.4 and $0.2 \mathrm{~km}^{2}$; their surface loss in 2008 varied between 21 and 48\%, with greater fractional area losses for the glaciers shorter than or equal to $1 \mathrm{~km}$.

\subsection{The meteorological data}

The glacier length fluctuations are driven by changes in temperature and precipitation; generally, temperature plays a predominant role (Mackintosh and others, 2002; Giesen and Oerlemans, 2010). In this work, we use the air temperature data from nine stations (Fig. 1, panel b) obtained from the HISTorical instrumental climatology surface time series of the greater ALPine region (HISTALP, http://www.zamg.ac.at/ histalp/). The stations are located within a distance of 100 $\mathrm{kms}$ around the study area, and their elevations range from 272 to $2247 \mathrm{~m}$.

At the mid-latitudes, glacier behaviour is controlled by the sequence accumulation-ablation seasons that define the hydrological year. The mean annual temperature variations have been obtained by averaging the annual temperature fluctuations at the nine stations over the hydrological year, from October to September. This average attenuates potential spurious oscillations which may be present in a single station time series. Figure 2 reports the temperature fluctuations along with their 11-year moving average which is used in this paper as a reference for the model validation. The choice of the 11-year moving average resulted from a trade-off between the need to preserve the long-time variations of the signal and to omit the oscillations with periods shorter than 5 years. Linear regressions of the filtered signal from 1930 to 2015 and from 1980 to 2015 yield temperature increases of 1.8 and $1.5^{\circ} \mathrm{C}$, respectively.

Because of the high variability of precipitation and the strong influence of orography, we have used precipitation data from the Bressanone station ( $\# 2$ in Fig. 1, panel b), the closest to the considered glaciers. Annual and winter precipitation amounts (accumulation season), expressed in $\mathrm{mm}$ of water equivalent, do not show any trend over the period 1930-2015, but rather long-term oscillations are evident in the 11-year moving average curve (Fig. 3).

\section{THE MODEL}

The model proposed by Leclercq and Oerlemans (2012) estimates the air temperature $T^{\prime}{ }_{\mathrm{m}}(t)$ fluctuations from the glacier length fluctuations $L^{\prime}(t)$, i.e.,

$$
T_{\mathrm{m}}^{\prime}(t)=-\left(L^{\prime}(t)+\tau \mathrm{d} L^{\prime}(t) / \mathrm{d} t\right) / C_{\mathrm{s}}
$$


Table 1. Area $A$, length $L$ and slope $\alpha$ of the nine measured glaciers of the Western Tauri.

\begin{tabular}{|c|c|c|c|c|c|c|c|c|c|c|c|}
\hline Glacier & & ID-code & WGI-code & type & $\begin{array}{c}\mathrm{A}\left(\mathrm{km}^{2}\right) \\
1982\end{array}$ & $\begin{array}{c}\mathrm{A}\left(\mathrm{km}^{2}\right) \\
2008\end{array}$ & $\begin{array}{c}\Delta A(\%) \\
1982-2008\end{array}$ & $\begin{array}{l}\mathrm{L}(\mathrm{m}) \\
1982\end{array}$ & $\begin{array}{l}\mathrm{L}(\mathrm{m}) \\
2015\end{array}$ & $\begin{array}{c}\Delta L(\%) \\
1982-2015\end{array}$ & $\begin{array}{l}\alpha \\
\left.()^{\prime}\right)\end{array}$ \\
\hline Gran Pilastro & $\mathrm{a}$ & 893 & IT4L00121313 & $\mathrm{v}$ & 2.62 & 1.73 & 34 & 3700 & 3135 & 15 & 14 \\
\hline Lana & $b$ & 913 & IT4L00123223 & $v$ & 1.69 & 1.27 & 25 & 2900 & 2595 & 10 & 25 \\
\hline Quaira Bianca & c & 889 & IT4L00121309 & $\mathrm{m}$ & 1.41 & 1.03 & 27 & 2800 & 2281 & 20 & 20 \\
\hline $\begin{array}{l}\text { Eastern-central } \\
\text { Ries }\end{array}$ & d & 929 & IT4L00123311 & $\mathrm{m}$ & 1.97 & 0.89 & 55 & 2500 & 1997 & 20 & 12 \\
\hline Eastern Neves & $\mathrm{e}$ & 902 & IT4L00123109 & $\mathrm{m}$ & 2.27 & 1.17 & 48 & 2200 & 1565 & 29 & 28 \\
\hline Western Ries & f & 930 & IT4L00123312 & $\mathrm{m}$ & 2.57 & 1.93 & 25 & 2200 & 1433 & 34 & 11 \\
\hline Rosso Destro & g & 920 & IT4L00123236 & $\mathrm{m}$ & 1.00 & 0.62 & 38 & 1700 & 1293 & 34 & 11 \\
\hline Collalto & $\mathrm{h}$ & 927 & IT4L00123310 & $\mathrm{m}$ & 0.83 & 0.50 & 40 & 1600 & 1367 & 14 & 26 \\
\hline Valle del Vento & i & 919 & IT4L00123233 & $v$ & 0.36 & 0.19 & 47 & 1200 & 975 & 18 & 33 \\
\hline
\end{tabular}

ID codes refer to the Italian Glacier Inventory (Consiglio Nazionale delle Ricerche - Comitato Glaciologico Italiano, 1959-1962). Areas and lengths have been collected from the WGI in 1982. Areas in 2008 are from Smiraglia and Diolaiuti (2015). The lengths in 2015 have been obtained from field measurements (Comitato Glaciologico Italiano, 1981-2016) starting from 1982 lengths. $\alpha$ is the angle between the glacier surface and the horizon. a-i refer to the glacier locations in Figure 1, panel a. The glaciers are reported in order of decreasing length; $v=$ valley glacier, $\mathrm{m}=$ mountain glacier.

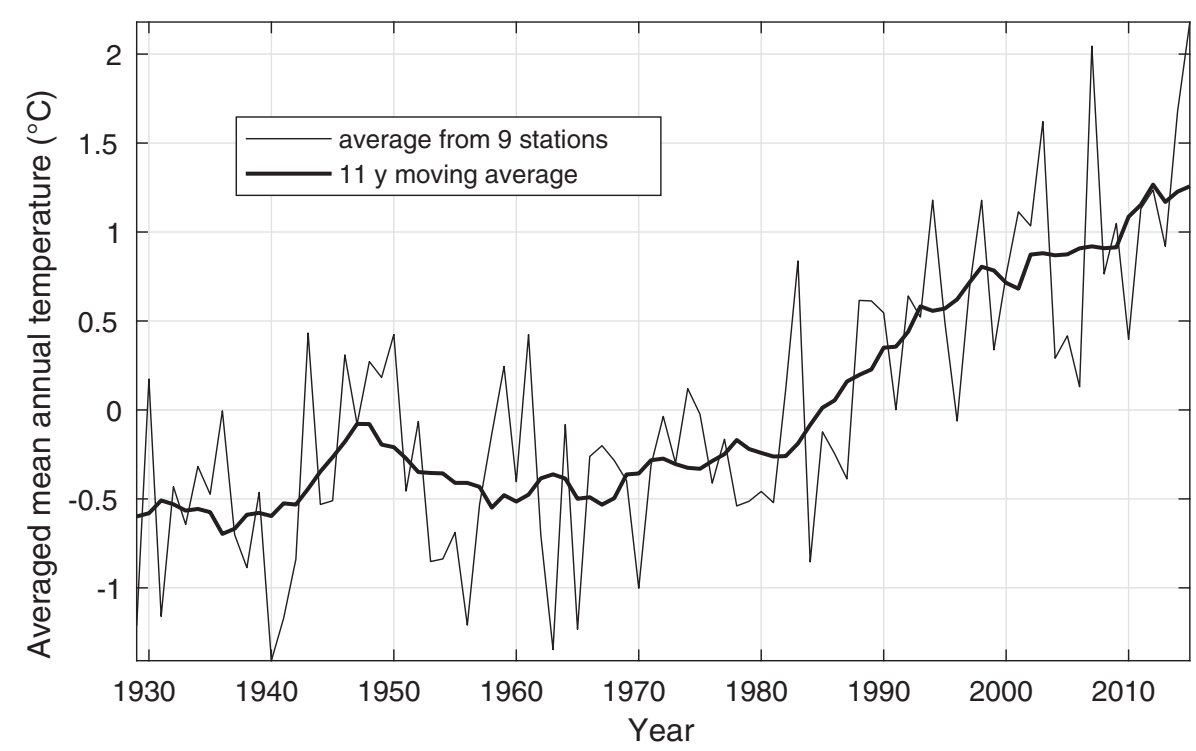

Fig. 2. The temperature fluctuations derived by averaging the time series at the stations listed in Figure 1 . The bold line is the 11 -year moving average.

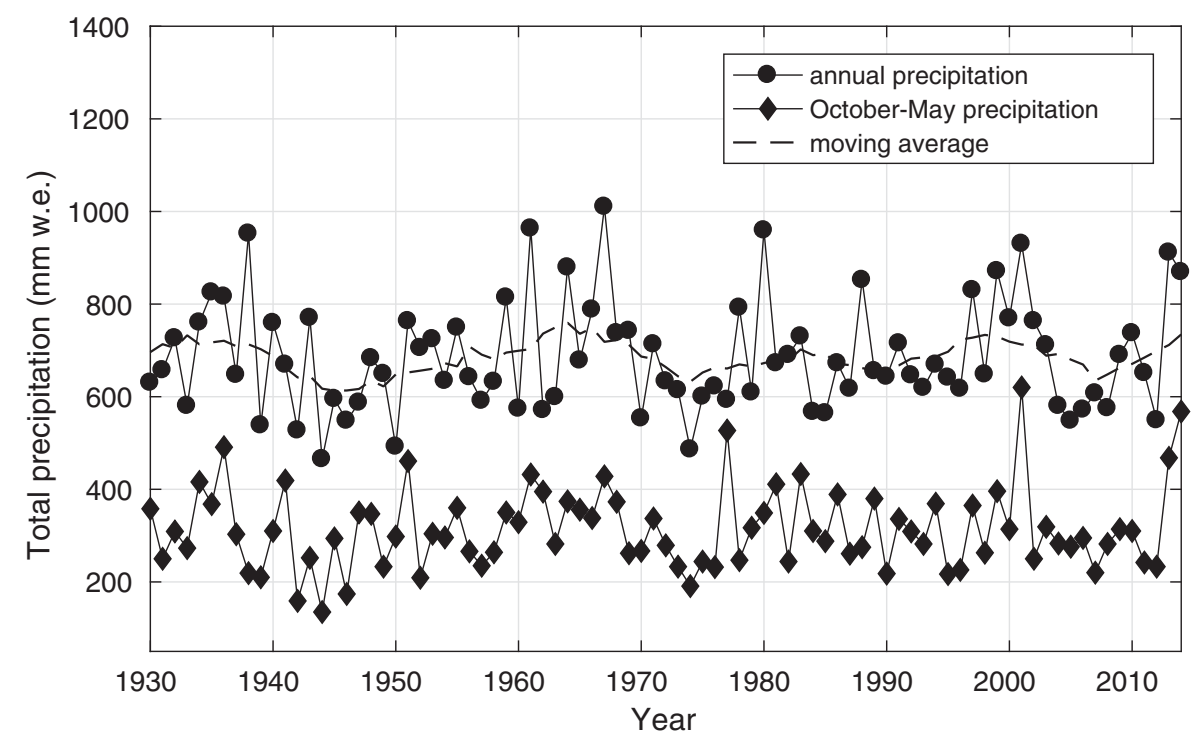

Fig. 3. The annual and winter total precipitation between 1930 and 2015 in Bressanone, Italy, expressed in mm of water equivalent (w.e.). The dashed lines represent the 11-year moving averages. 
Table 2. Area $A$, length $L$ and slope $\alpha$ of the selected unmeasured mountain glaciers reported in order of decreasing length.

\begin{tabular}{|c|c|c|c|c|c|c|c|c|}
\hline Glacier & & ID-code & WGI-code & $\begin{array}{c}\mathrm{A}\left(\mathrm{km}^{2}\right) \\
1982\end{array}$ & $\begin{array}{c}\mathrm{A}\left(\mathrm{km}^{2}\right) \\
2008\end{array}$ & $\begin{array}{c}\Delta A(\%) \\
1982-2008\end{array}$ & $\begin{array}{l}\mathrm{L}(\mathrm{m}) \\
1982\end{array}$ & $\begin{array}{l}\alpha \\
\left({ }^{\circ}\right)\end{array}$ \\
\hline Predoi & j & 912 & IT4L00123222 & 0.91 & 0.59 & 35 & 1800 & 20 \\
\hline Eastern Gran Vedretta & k & 883 & IT4L00121302 & 0.42 & 0.28 & 33 & 1500 & 30 \\
\hline Western Neves & I & 900 & IT4L00121309 & 0.91 & 0.49 & 46 & 1400 & 28 \\
\hline Rio Torbo & $\mathrm{m}$ & 908 & IT4L00123210 & 1.39 & 1.10 & 21 & 1300 & 23 \\
\hline Rosso Sinistro & $\mathrm{n}$ & 921 & IT4L00123237 & 0.45 & 0.34 & 24 & 1300 & 27 \\
\hline Rio Nero & $\mathrm{p}$ & 920 & IT4L00123205 & 0.81 & 0.42 & 48 & 1000 & 22 \\
\hline South-western Punta Rio Torbo & $q$ & $908 a$ & IT4L00123211 & 0.45 & 0.24 & 47 & 900 & 21 \\
\hline Southern Punta Bianca & $r$ & 895 & IT4L00123101 & 0.30 & 0.17 & 43 & 900 & 17 \\
\hline Northern Punta Bianca & $\mathrm{s}$ & 897 & IT4L00123104 & 0.24 & 0.14 & 42 & 800 & 20 \\
\hline Guardia Alta & $\mathrm{t}$ & $893 a$ & IT4L00121314 & 0.31 & 0.16 & 48 & 700 & 15 \\
\hline
\end{tabular}

ID codes refer to Consiglio Nazionale delle Ricerche - Comitato Glaciologico Italiano (1959-1962). Areas, and length have been derived from data collected for WGI in 1982. Areas in 2008 are from Smiraglia and Diolaiuti (2015). j-t refer to the glacier locations in Figure 1, panel a. $\alpha$ is the angle between the glacier surface and the horizon.

where $L^{\prime}(t)(m)$ is the variation in the glacier length with respect to its average value, $\mathrm{d} L^{\prime}(t) / \mathrm{d} t\left(\mathrm{~m} \mathrm{a}^{-1}\right)$ is the glacier variation rate, $C_{\mathrm{s}}$ is the climate sensitivity $\left(\mathrm{m} \mathrm{K}^{-1}\right)$ and $\tau$ is the glacier response time (year). The climate sensitivity $C_{s}$ is defined as

$$
C_{\mathrm{s}}=\left(\bar{P}_{\mathrm{ann}}\right)^{1 / 2} /(\mathrm{c} 1 * s)
$$

where $\bar{P}_{\text {ann }}\left(\mathrm{m} \mathrm{a}^{-1}\right)$ is the mean annual precipitation at the glacier site and $s$ is the glacier slope. The response time $\tau$ is

$$
\tau=c_{2} /\left(\beta s(1+20 s)^{1 / 2} L^{1 / 2}\right)
$$

where $\beta=c_{3}\left(\bar{P}_{\mathrm{ann}}\right)^{1 / 2}\left(\mathrm{a}^{-1} \mathrm{~m}^{-1 / 2}\right)$ is the balance gradient with the constant $c_{3}=0.006$ obtained from calibration with numerical simulations (Oerlemans, 2005). The constants $c_{1}=0.0078 \pm 0.0004$ and $c_{2}=1.35 \pm 0.14$ result from a recalibration carried out by Zecchetto and others (2017); this step is necessary because when the original coefficients are used, the temperature fluctuations produced by the model do not reproduce those from the observations. According to Leclercq and Oerlemans (2012), the response time $\tau$ is defined as the time the glacier requires to reach $\left(1-\mathrm{e}^{-1}\right)$ of the final length change after a stepwise perturbation of the climatic forcing. $\tau$ is also defined in Christian and others (2018) as the glacier response time-scale.

Equation (1) is a linear differential equation, which may be solved as

$$
L_{\mathrm{m}}^{\prime}(t)=-\left(1-\mathrm{e}^{-t / \tau}\right) C_{\mathrm{s}} T^{\prime}
$$

for an initial condition $L^{\prime}(t=0)=0$ and $C_{s}$ and $T^{\prime}$ constant. This equation provides the glacier length fluctuations $L_{\mathrm{m}}^{\prime}$ once the temperature variations $T^{\prime}$ are known. This solution is time dependent and describes the system in equilibrium at $t=\infty$; i.e., the glacier's response to a change in the temperature forcing would take an infinite time to reach a new equilibrium. The equation $L_{\mathrm{m}}^{\prime}(\infty)=C_{\mathrm{s}} T^{\prime}$ is therefore valid for equilibrium conditions, which are never reached. For $t=2 \tau$ the equilibrium is approached with $69 \%$ and Eqn (4) provides the value of $L_{\mathrm{m}}^{\prime}$ at this percent of equilibrium.

The model can be used provided the following condition (Oerlemans, 2011; Leclercq and Oerlemans, 2012) is respected

$$
\sigma_{L} / L_{0} \ll 1
$$

where $\sigma_{L}$ is the standard deviation of the glacier length and $L_{0}$ is the glacier length (or mean) over the period considered. This condition states that the model can be applied only if the glacier variations are small with respect to its length; thus, implicitly, the model does not account for all the nonlinear and local factors influencing a glacier's life, such as fragmentation and the consequent decoupling of length variations from the local temperature. Neither does the model account for changes in ice flow or debris cover. The results provided in this paper are all compatible with Eqn (5), and all the conclusions reached must be viewed in light of this constraint.

Both Eqns (1) and (4) need, as input, continuous and smoothed time series of $L^{\prime}$ and $T^{\prime}$, respectively. The time series of the glacier fluctuations with missing data have been interpolated using a shape-preserving cubic interpolation and then filtered using the Butter low-pass filter with a cutoff period of 15 years. The time series of $T^{\prime}$ have been smoothed with an 11-year moving average.

In the following sections, we use the term mean temperature (length) anomaly to refer to the quantity $\left\langle T^{\prime}-\overline{T^{\prime}}\right\rangle(t)$ (or $\left.L^{\prime}\right)$, where the overline indicates the mean over time and \langle\rangle the average over the glacier length. The superscripts $M$ and $V$ refer to mountain and valley glaciers respectively. Thus, all the time series of each kind $\left\langle T_{\mathrm{m}}^{\prime}\right\rangle(t)$ have a null mean.

The model has been applied to small mountain and valley glaciers over the period 1980-2015 to evaluate its performance and over the period 2015-2100 to estimate the glaciers' life expectancies.

\section{THE MODEL APPLIED TO THE MOUNTAIN GLACIERS}

In this section, we test the performance of the linear model when applied to the small mountain glaciers over the period 1980-2015 in two ways: by assessing the temperature anomaly and by evaluating the relative snout position.

To perform the first test, we rely only on the measured mountain glaciers (Table 1), since we need the observed glacier snout variations to obtain the temperature fluctuations 


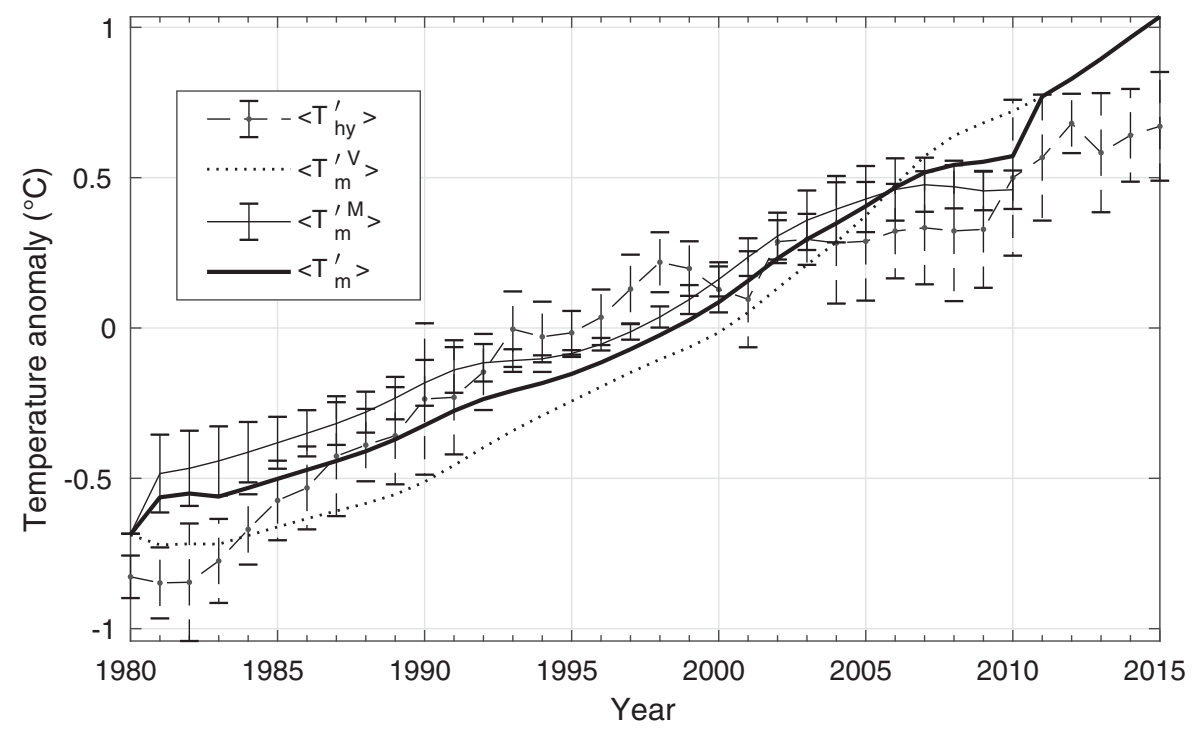

Fig. 4. The temperature anomaly $\left\langle T_{\mathrm{m}}^{\prime M}\right\rangle(t)$ for the measured mountain glaciers (solid line) along with the observed temperature anomaly $\left\langle T_{h y}^{\prime}\right\rangle(t)$ (dashed line) and the mean model temperature anomaly $\left\langle T_{\mathrm{m}}^{\prime}\right\rangle(t) \cdot\left\langle T_{\mathrm{m}}^{\prime}\right\rangle(t)$ for the valley glaciers (dotted line) is reported for reference.

(Eqn (1)). For the second test, we use all the mountain glaciers available, both measured and unmeasured, since the forcing of the model is the temperature (Eqn (4)). These reconstructions do not include the Quaira Bianca (889) and Eastern Neves (902) glaciers, since they were used for the calibration of $c_{1}$ and $c_{2}$ (Eqns (2) and (3)) (Zecchetto and others, 2017). As reported in the model description, the model can be applied only to the glaciers that satisfy Eqn (5). While for the four measured mountain glaciers, $\sigma_{L} / L$ satisfies this condition, for the unmeasured glaciers, the ratio is unknown. Therefore, Eqn (5) must be verified a posteriori from the model estimate of $L_{\mathrm{m}}$. For these glaciers, $\sigma_{L_{\mathrm{m}}} / L_{\mathrm{m}}$ has been estimated over running windows of 15 years showing that only for the six longest unmeasured glaciers (Table 2) is Eqn (5) satisfied.

The result of the first test is provided in Figure 4: it presents the model mean temperature anomaly $\left\langle T_{\mathrm{m}}^{\prime}\right\rangle(t)$ (solid bold line) as function of time (t), obtained for the mountain glaciers $\left\langle T_{\mathrm{m}}^{\prime \mathrm{M}}\right\rangle(t)$ (solid line) and the valley glaciers $\left\langle T_{\mathrm{m}}^{\prime v}\right\rangle(t)$ (dotted line), along with the observed mean temperature anomaly $\left\langle T_{h y}^{\prime}\right\rangle(t)$ (dashed line). The error bars on $\left\langle T_{\mathrm{m}}^{\prime \mathrm{M}}\right\rangle(t)$ represent the standard deviation of the temperature fluctuations derived by the model for the four measured mountain glaciers, while the standard deviations $\left\langle T_{h y}^{\prime}\right\rangle(t)$ are based on the temperature fluctuations measured at the different meteorological stations. After 2010, the model mean temperature for the mountain glaciers has not been derived for lack of suitable data. The modelled temperature increase of $\sim 1.7^{\circ} \mathrm{C}$ agrees with the general trend exhibited by the temperatures used in this study. Therefore, it seems reasonable that the model can also be used for the mountain glaciers.

The second test was carried out by using the mean air temperature as presented in (Fig. 2) and Eqn (4) with $t=2 \tau$. Figure 5 reports the mean model results for all (measured and unmeasured) mountain glaciers $\left\langle L_{\mathrm{m}}^{\prime M}\right\rangle(t)$, with the mean $\left\langle L^{\prime}\right\rangle(t)$ for the measured mountain glaciers and the $\left\langle L_{\mathrm{m}}^{\prime}\right\rangle(t)$ of the valley glaciers for reference. The average length retreat of $333 \mathrm{~m}$ provided by the model for the valley glaciers is consistent with the observed average length retreat of $365 \mathrm{~m}$ and with the mean climate sensitivity $\left\langle C_{\mathrm{s}}\right\rangle$ of $238 \mathrm{~m} \mathrm{~K}^{-1}$ (Table 3 ).
The mean of the modelled length fluctuations of the mountain glaciers $\left\langle L_{m}^{\prime}\right\rangle(t)$ lies between those of the valley $\left\langle L_{\mathrm{m}}^{\prime v}\right\rangle(t)$ and the observed $\left\langle L^{\prime}\right\rangle(t)$ fluctuations. For the six longest unmeasured glaciers, the average area loss from 1982 to 2008 is $\sim 34 \%$. For the measured mountain glaciers, a $39 \%$ loss of area corresponds to a mean length decrease of $25 \%$. Since measured and unmeasured mountain glaciers pertain to the same glacier type and have similar sizes, a similar length reduction for the unmeasured glaciers is expected: the model results (Table 3 ) indicate length reductions between 12 and 32\%. The mean modelled length reduction of the four measured mountain glaciers $\left\langle L_{m}^{\prime M}\right\rangle$ (491 m) is comparable with their mean observed retreat $\left\langle L^{\prime}\right\rangle$ of $477 \mathrm{~m}$. The mean climate sensitivity $\left\langle C_{\mathrm{s}}\right\rangle$ of all mountain glaciers, measured and unmeasured, is $290 \mathrm{~m} \mathrm{~K}^{-1}$.

The results of the comparison between the model and the observations in the past (1980-2015) indicate that the model is sufficiently reliable to be used for future projections forced by climatological temperatures.

\section{GLACIER LIFE EXPECTANCY}

To investigate a glacier's future behaviour under the global warming scenario, we have used the temperature projections of the A1B emission scenario, which ....describes a future world of very rapid economic growth, global population that peaks in mid-century and declines thereafter, and the rapid introduction of new and more efficient technologies (Nakićenović and others, 2000). In particular, the A1B scenario is derived under a supposed balance of fossil intensive and non-fossil energy sources.

In the Alps, the A1B scenario indicates a temperature increase of $0.25^{\circ} \mathrm{C}$ per decade until the mid of the $21 \mathrm{st}$ century and of $0.36^{\circ} \mathrm{C}$ per decade in the second half of the century, i.e., $2.7^{\circ} \mathrm{C}$ from 2015 to 2100 . These temperature projections have been used by Gobiet and others (2014) to analyse future climate change in the European Alps. This temperature projection is more severe than the intermediate RCP4.5 scenario (emissions peak around 2040, then decline), which for the Tyrol area reports an increase of 


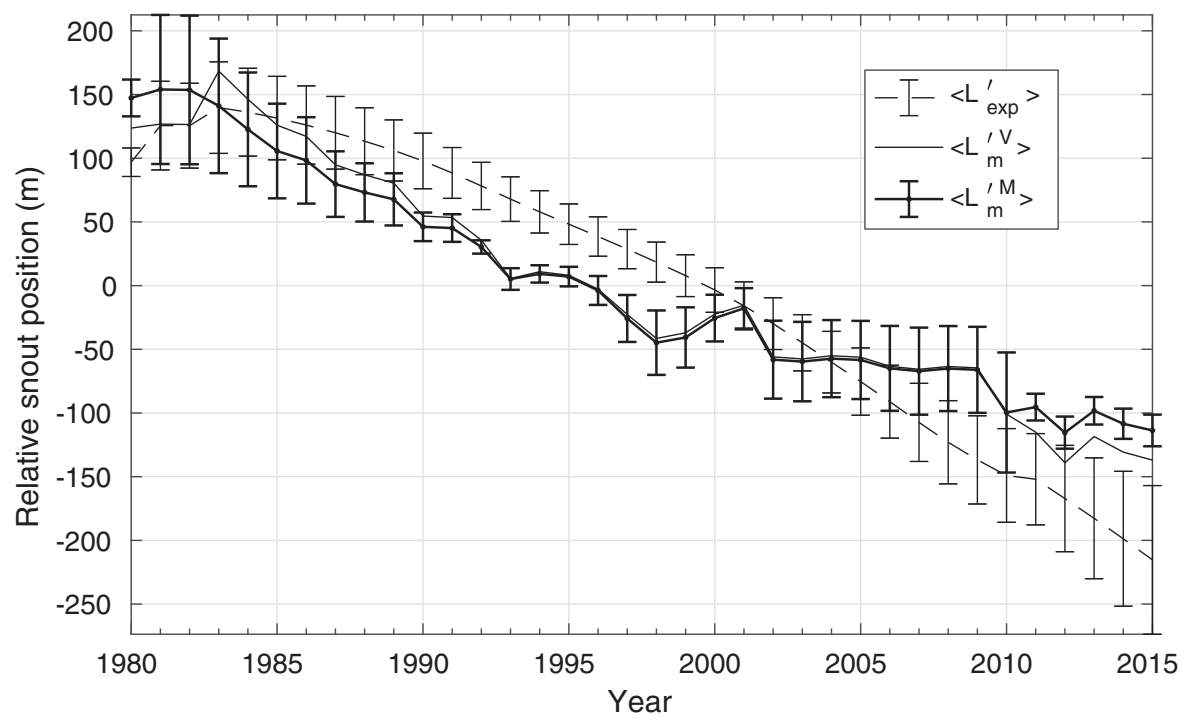

Fig. 5. The model glacier mean length anomaly $\left\langle L_{m}^{\prime}\right\rangle$ for the mountain glaciers (bold solid line). Dashed line: $\left\langle L^{\prime}\right\rangle(t)$ obtained from in situ measurements related to the four measured mountain glaciers. Solid line: $\left\langle L_{m}^{\prime v}\right\rangle(t)$ for the valley glaciers.

$2^{\circ} \mathrm{C}$ at the end of this century, and less severe than the RCP8.5 scenario (business-as-usual), which indicates an increase of $4.6^{\circ} \mathrm{C}$ for Tyrol (IPCC, 2014; Chimani and others, 2017). The temperature increase from 2015 to 2100 from the A1B scenario described above is plotted in Fig. 6 (solid and dotted lines), where the observed temperature variations from 1980 to 2015 are added for reference (dashed line). The presented scenario is used as forcing in Eqn (4) to derive the climatological glacier length variations.

As noted above, Eqn (5) must be satisfied to consider the model's results reliable. Of course, the ratio $\sigma_{L} / L$ is not known for the future; therefore, it has been obtained from the model estimate of $L_{\mathrm{m}}$ over running windows of 15 years, and Eqn (5) has been verified a posteriori. Fig. 7a presents the model-derived $\sigma_{\mathrm{Lm}} / L_{\mathrm{m}}$ as a function of time for the period 2015-2100 and all glaciers considered. For two glaciers, the West Ries (930) and East Central Ries (929), the model is applicable only until the 2050s, while for the other glaciers, the model is applicable until the end of this century.

Figure $7 \mathrm{~b}$ reports the glacier length variations as a function of time for the periods of applicability of the linear model given by Eqn (4) and depicted in Fig. 7a. These results show the retreat of the glaciers until they behave linearly, in other words, until the Eqn (5) is satisfied. Otherwise, the linear model cannot be used because highly nonlinear processes of glacier decay are dominant. The length decreases for the valley glaciers (solid lines) are less than those for the mountain glaciers (dashed lines). For two mountain glaciers, the condition of applicability of the linear model holds only until 2055 (East Central Ries glacier) and 2066 (West Ries glacier). These glaciers show retreats of $\sim 40 \%$ by 2060 .

By the end of this century, the total length retreat is estimated to be from 20 to $60 \%$, with expected length reductions of $20-35 \%$ for valley glaciers and of $35-60 \%$ for mountain glaciers with length $>1 \mathrm{~km}$.

\section{DISCUSSION}

For the glaciers of the Swiss Alps, Huss and Fischer (2016), based on glaciers smaller than $0.5 \mathrm{~km}^{2}$ and climate scenarios A1B, A2, RCP3PD, estimated that $71 \%$ of the glaciers will have disappeared by 2040. The lifespan of the Western Tauri glaciers $\left(0.01-1.93 \mathrm{~km}^{2}\right)$, based on the length

Table 3. The model results for valley and mountain glaciers.

\begin{tabular}{|c|c|c|c|c|c|c|c|c|}
\hline Glacier & & ID-code & type & $\begin{array}{c}C_{\mathrm{s}} \\
\left(\mathrm{m} \mathrm{K}^{-1}\right)\end{array}$ & $\begin{array}{c}\tau \\
\text { (year) }\end{array}$ & $\begin{array}{l}L_{\mathrm{m}} \\
(\mathrm{m})\end{array}$ & $\begin{array}{c}\Delta L_{\mathrm{m}} \\
(\mathrm{m})\end{array}$ & $\begin{array}{l}\Delta L_{m} \\
(\%)\end{array}$ \\
\hline Gran Pilastro & $\mathrm{a}$ & 893 & valley* & 359 & 6 & 3204 & 496 & 13 \\
\hline Lana & b & 913 & valley* & 213 & 3 & 2599 & 301 & 10 \\
\hline Valle del Vento & $\mathrm{i}$ & 919 & valley* & 143 & 3 & 999 & 201 & 17 \\
\hline Eastern-central Ries & $d$ & 929 & mountain * & 715 & 19 & 1690 & 810 & 32 \\
\hline Western Ries & $f$ & 930 & mountain * & 532 & 13 & 1572 & 628 & 29 \\
\hline Rosso Destro & $\mathrm{g}$ & 920 & mountain * & 218 & 4 & 1392 & 308 & 18 \\
\hline Collalto & $\mathrm{h}$ & 927 & mountain * & 252 & 5 & 1382 & 218 & 14 \\
\hline Predoi & j & 912 & mountain & 276 & 6 & 1410 & 390 & 22 \\
\hline Eastern Gran Vedretta & $\mathrm{k}$ & 883 & mountain & 131 & 2 & 1315 & 185 & 12 \\
\hline Western Neves & I & 900 & mountain & 238 & 5 & 1064 & 336 & 24 \\
\hline Rio Torbo & $\mathrm{m}$ & 908 & mountain & 208 & 4 & 1006 & 294 & 23 \\
\hline Rosso Sinistro & $\mathrm{n}$ & 921 & mountain & 131 & 21 & 1115 & 185 & 14 \\
\hline Di Dentro & o & 904 & mountain & 199 & 4 & 819 & 281 & 26 \\
\hline
\end{tabular}

The climate sensitivity $C_{\mathrm{s}}$ and response time $\tau$ are from Eqns (2) and (3). The model lengths $L_{\mathrm{m}}$ refer to 2015, and their reduction $\Delta L_{\mathrm{m}}$ is between 1982 and 2015. ( ${ }^{*}$ measured glaciers). Letters refer to the glacier locations in Figure 1, panel a. 


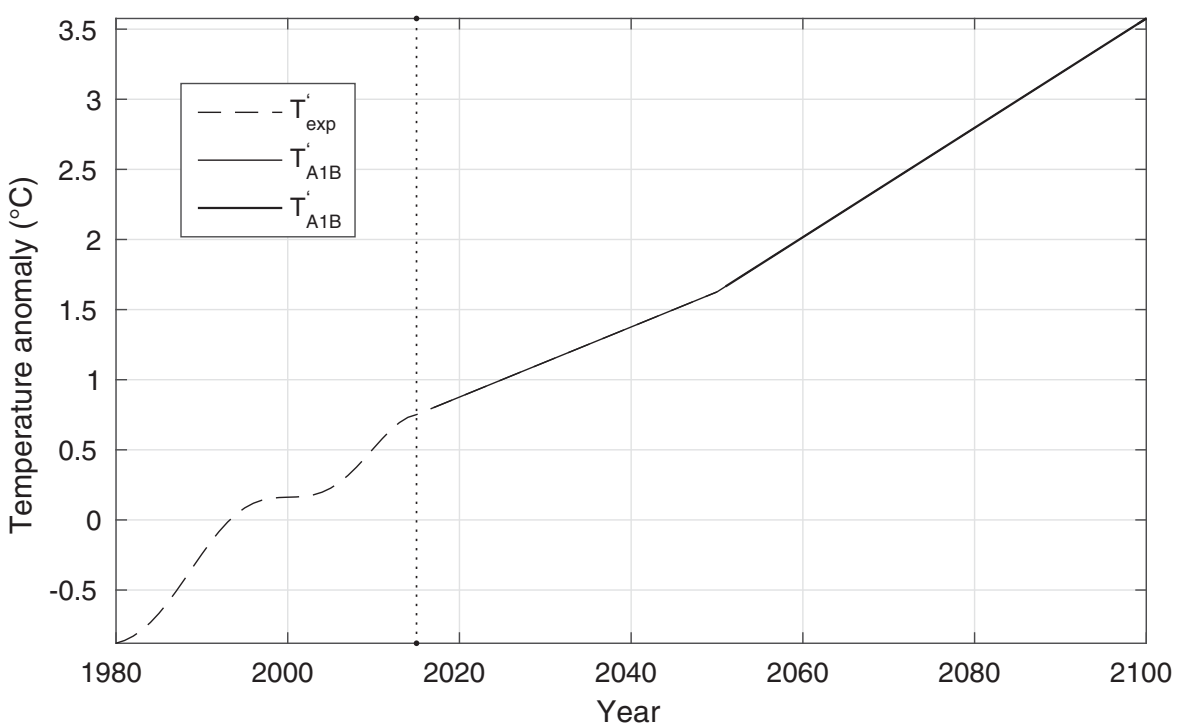

Fig. 6. The climatological forcing temperature anomaly used to estimate the future changes in glaciers. Solid and dotted lines: projections derived from the A1B scenario until and after 2050, respectively (Nakićenović and others, 2000). The observed temperature variations from 1980 to 2015 (dashed line) are reported for reference. The vertical line indicates the start time for the computation of the climatological glacier length variations.

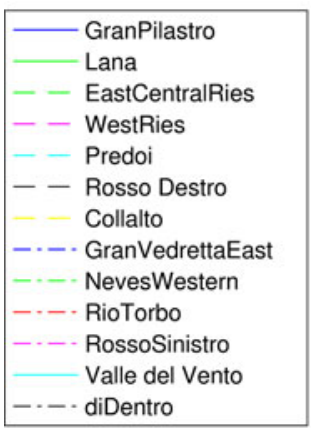
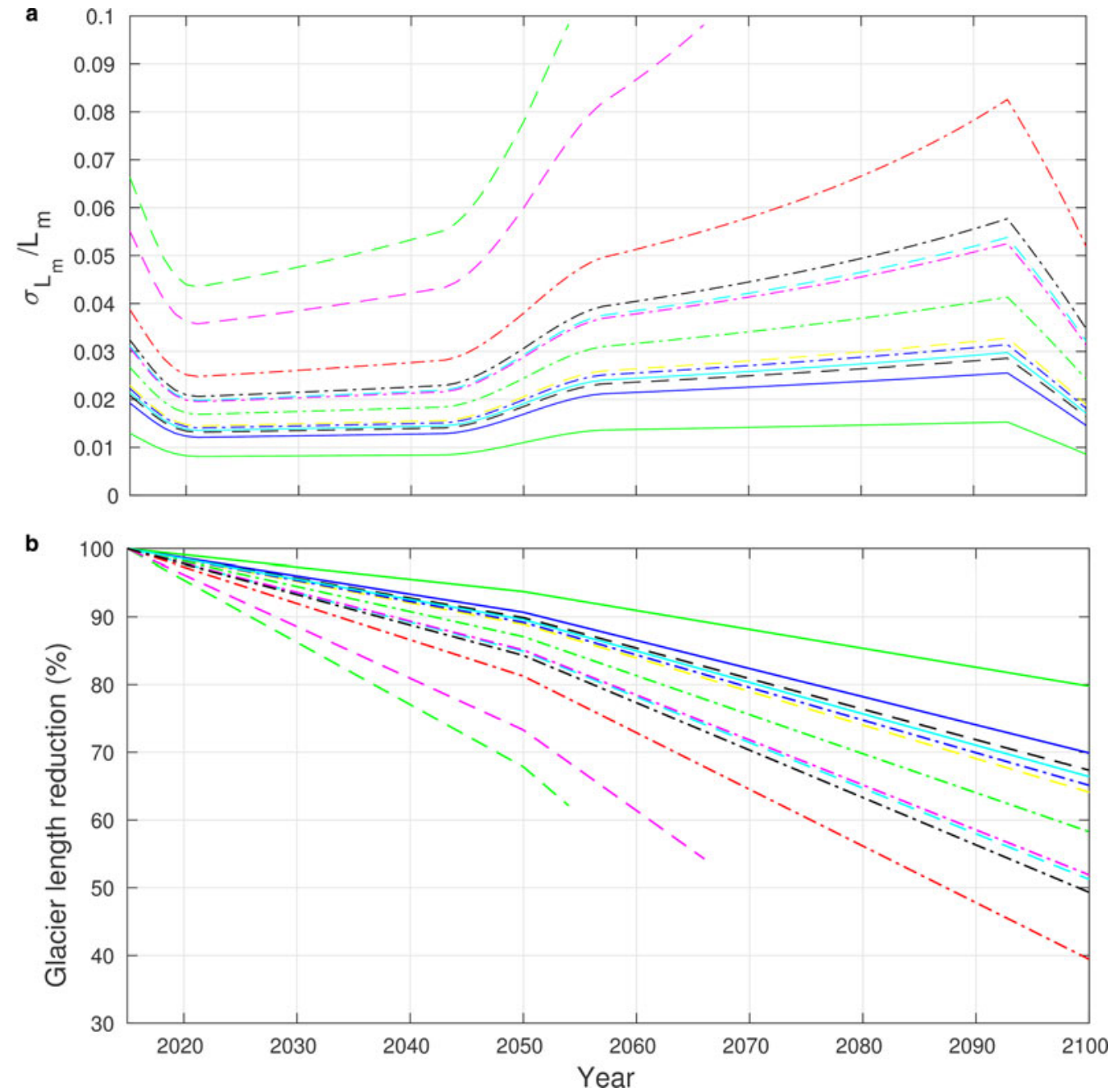

Fig. 7. The changes in valley and mountain glacier lengths obtained using the temperature scenario as presented in Figure 6 . Panel a: modelderived $\sigma_{L_{\mathrm{m}}} / L_{\mathrm{m}}(t)$ as a function of time. Panel b: percentage of the glacier length variations as a function of time. Valley glaciers: solid lines; measured mountain glaciers: dashed lines; unmeasured mountain glaciers: dotted lines. The legend denotes the names of the glaciers in order of decreasing length. 
reductions expected by 2100 under climate scenario A1B, seems higher than the life expectancy predicted for the Swiss Alps glaciers. Furthermore, as shown in Table 1, a decrease in length of 10-34\% over the period 1982-2015 corresponds to a surface area reduction of $25-55 \%$. The modelled length reductions of $35-60 \%$ of the mountain glaciers with length $>1 \mathrm{~km}$ by the end of the century (Fig. 7b) can therefore be the result of surface area reductions $>60 \%$. For mountain glaciers with lengths $\leq 1 \mathrm{~km}$, surface area reductions far $>60 \%$ are expected. These area losses lead to a general fragmentation into smaller units with consequent acceleration of the retreat rate, given the positive feedback due to thermal radiation from now ice-free terrain observed at the snout of some glaciers (Comitato Glaciologico Italiano, 1981-2016) and to the decrease in glacier albedo caused by several years with negative mass balance (Paul and others, 2005; Haeberli and others, 2007). The expected length reduction obtained from the linear model (Fig. 7b) also shows that valley glaciers with reductions of $20-35 \%$ have the highest life expectancy.

To achieve an overall assessment of the length reduction of the Western Tauri glaciers, the 26 glaciers so far excluded because their area losses exceed 50\% between 1982 and 2008 must also be considered. In this time interval, these glaciers underwent a mean surface retreat of $61 \%$ with an area reduction up to $90 \%$. These glaciers represent the following types: glaciers with surface areas between 0.05 and $1 \mathrm{~km}^{2}$ in 1982 , now $<0.05 \mathrm{~km}^{2}$ (5 glaciers); glaciers with surface reductions of $60-90 \%$ over the period 1982 to 2008 (23 glaciers); and/or glaciers already fragmented in 2008 (14 glaciers) by the positive feedback due to thermal radiation derived from now ice-free rock outcrops. Among these 26 glaciers, none is in the potentially favourable situation to be avalanche-fed at sites that are radiation-protected and at low elevation and thus sensitive to increasing winter precipitation. The interaction of these negative feedbacks described by Huss and Fischer (2016) for the Swiss Alps, by Colucci (2016) and Carturan and others (2013a) in the Julian Alps and by DeBeer and Sharp (2009) for the Monashee Mountains (Canada) counteracts the glacier decay. Although almost all presented glaciers are avalanche-fed, the southern exposure makes the survival of some of these glaciers impossible. For other glaciers, such as the Cima Dura glacier (between glaciers $f$ and $m$ in Fig. 1), even though they are avalanche-fed glaciers located at low elevations in radiation-protected northern locations, they are already fragmented into smaller ice bodies and subjected to rapid disintegration (Treyer, 2012). A length reduction more severe than that presented in Fig. 7 is thus likely for these 26 glaciers, and they could be considered already disappearing.

Since 1982, the total area loss for the Western Tauri glaciers is $40 \%$. From 1987 to the 2000s, in the nearby OrtlesCevedale group, only $23 \%$ of the glacierized area was lost: this minor reduction seems due to the widespread negative feedbacks on glacier wastage observed in this glacier system, such as an increase in debris cover and a decrease in clear-sky radiation during summer, due to increased topographic shading (Carturan and others, 2013b). The 40\% shrinkage observed for the Western Tauri glaciers agrees with the $48 \%$ recorded in the Western Alps by Nigrelli and others (2015) for the same period. Compared with the $13 \%$ area loss from the 1930s to 1960s, the measured decline confirms the current historically unprecedented glacier shrinkage (Haeberli and others, 2007; Paul and others, 2007; Zemp and others, 2015). With some exceptions, the observed reductions are inversely proportional to size in accordance with previous observations on other glaciers in the Alps (Serandrei-Barbero and others, 1999; Paul and others, 2004, 2011; Diolaiuti and others, 2012); therefore, an even faster glacial area loss is expected.

The glacier geometry (slope and length) represents the main factor controlling the glacier tongue reaction (Hoelzle and others, 2003) and defines the climate sensitivity $C_{\mathrm{s}}$ and response time $\tau$ (Eqns (2) and (3)). On the 169 glaciers analysed by Oerlemans (2005) in different regions of the world, $\tau$ ranges from 10 years for the steepest glaciers to a few hundreds of years for the largest glaciers with smaller slopes; $C_{\mathrm{s}}$ is between $1000 \mathrm{~m} \mathrm{~K}^{-1}$ and $10000 \mathrm{~m} \mathrm{~K}^{-1}$. On the northern side of the Eastern Alps (Oerlemans, 2007, 2012), the Vadret da Morteratch and Hintereisferner glaciers, both $\sim 7 \mathrm{~km}$ long, have $\tau \approx 33$ years; Kesselwandferner and Vadret da Palü glaciers, $\sim 4 \mathrm{~km}$ long and steeper, have $\tau$ from 2 to 4 years. On the Italian side of the Eastern Alps, the value of $\tau$ for three valley glaciers with lengths between 3 and $1 \mathrm{~km}$ is $\sim 3-4$ years, and the resulting $C_{\mathrm{s}}$ is between 174 and $234 \mathrm{~m} \mathrm{~K}^{-1}$ (Zecchetto and others, 2017). For the mountain and valley glaciers considered in this study, with lengths between 3 and $0.7 \mathrm{~km}$, the mean value of $C_{\mathrm{s}}(278$ $\mathrm{m} \mathrm{K}^{-1}$ ) is consistent with the ground data, and $\tau$ between 3 and 20 years agrees with other values observed in the Alps, which are generally between 10 and 20 years (Paul and others, 2004).

On the mountain glaciers, $\left\langle C_{\mathrm{s}}\right\rangle$ is $290 \mathrm{~m} \mathrm{~K}^{-1}$ with a large spread for individual glaciers. The exceptionally high $C_{\mathrm{s}}$ values of the Eastern-central Ries (929) and the Western Ries (930) glaciers (Table 3) are due to their gentle slopes and their elevations not exceeding $3000 \mathrm{~m}$ a.s.l. This situation implies that these glaciers are located below the current equilibrium line altitude, estimated at $\sim 3100 \mathrm{~m}$ on glaciers belonging to the Adige River basin (Zemp and others, 2007). Apart from these two most gently sloping glaciers whose $\tau$ is between 11 and 20 years, all the other have $\tau$ from 3 to 6 years.

On the valley glaciers, the results show less variability since larger glaciers generally tend to have gentler slopes (Paul and others, 2011; Oerlemans, 2012); the highest $C_{\mathrm{s}}$ value is $359 \mathrm{~m} \mathrm{~K}^{-1}$ for the largest glacier (Gran Pilastro, 893), and the lowest value is $143 \mathrm{~m} \mathrm{~K}^{-1}$ for the Valle del Vento (919) glacier, the smallest among the considered valley glaciers (Table 3). The ground surveys agree with these results: between 1980 and 2015, the average retreat rate of the Valle del Vento glacier was less than half the retreat rates of Gran Pilastro and Lana glaciers (Comitato Glaciologico Italiano, 1981-2016). These results of the linear model favour a longer survival for valley glaciers (Fig. 7b) and agree with the theoretical analyses of Bahr and others (1998) and Pfeffer and others (1998) which show that for the same climatic conditions, larger valley glaciers respond faster than smaller glaciers to perturbations in mass balance. This outcome occurs because larger valley glaciers push farther into the ablation zone.

In the present retreat phase, the primary classification appears ephemeral and somewhat subjective as the valley tongue is the most vulnerable and rapidly perishable glacier part (Carturan and others, 2013b). In this regard, the Rosso Destro glacier is today a mountain apron glacier (Cogley and others, 2011) while in contrast, the Lana and 


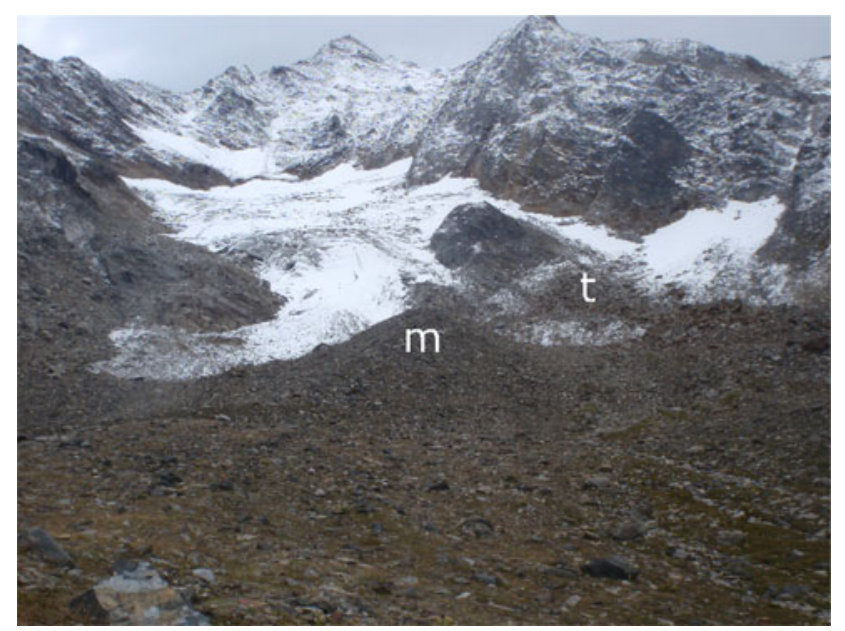

Fig. 8. The Valle del Vento (919) glacier in 2015. The medial moraine $m$ is located at the confluence of the two ablation tongues dating back to the Little Ice Age. The left tongue $t$ is now extinct, and the right terminus is hidden by debris cover, present only on the snout.

Valle del Vento glaciers are classified as mountain glaciers (Smiraglia and Diolaiuti, 2015), despite the fact that they still have evident valley tongues (Fig. 8). Despite the limits of the primary classification (Paul and others, 2009), the glacial morphology seems to be a possible discriminating factor of a glacier's response to climate variations, and only the valley glaciers seem expected to survive beyond the end of this century, even though they belong to the same dimensional classes as the mountain glaciers such as the Valle del Vento glacier.

\section{CONCLUSIONS}

In this work, we used a linear model to analyse the future changes in the Italian Western Tauri glaciers until 2100, forced by temperature increases according to the A1B scenario, as used before in the Alps by Gobiet and others (2014). To date, the model has generally been used for valley glaciers, but in this study, it was tested on small mountain type glaciers for the period between 1980 and 2015; then, it was also applied to unmeasured glaciers located in this area.

The comparison between the model results and the observations indicates that the model is sufficiently reliable to be used for future projections forced by climatological temperatures. The model, using a mean sensitivity $\left\langle C_{\mathrm{s}}\right\rangle$ of $278 \mathrm{~m} \mathrm{~K}^{-1}$ and forced by a temperature increase of $1.5^{\circ} \mathrm{C}$ from 1980 to 2015, produces results consistent with the average frontal retreat of $462 \mathrm{~m}$ obtained from the in situ measurements. For valley glaciers, the retreat rate decreases with decreasing length, probably prolonging their life, while mountain glaciers, generally smaller than valley glaciers, are more exposed to the temperature increase, which probably condemns them to disappear within a few decades.

By 2100, the model projections indicate a shortening of $20-35 \%$ for 2015 valley glacier lengths (3135-975 m) and far more than $35 \%$ for the mountain glacier lengths (1997$819 \mathrm{~m}$ ), resulting in an average area loss of more than $60 \%$. This expected strong average reduction in area has to be considered a lower bound value since progressive glacier shrinkage and fragmentation will also lead to increasing glacier melt under the same climatic conditions given the delayed effects of temperature increase due to response time. Furthermore, the climatological scenario adopted is an intermediate type (similar to the RCP4.5 scenario), and other more severe scenarios are far more likely at present.

In the Italian Western Tauri, mountain glaciers represent $\sim 95 \%$ of the glaciers. The projected large reduction of the modelled mountain glaciers by 2100 (> $>0 \%$ of area loss), together with the vanishing already under way of the 26 smallest mountain glaciers not treated by the model, would mean the extinction of almost the totality of the existing glaciers by the end of this century, possibly leaving only three valley glaciers to survive.

\section{ACKNOWLEDGMENTS}

The glacier frontal variation data have been downloaded from the World Glacier Monitoring Service (www.wgms. ch), and the meteorological data, from the Historical Instrumental Climatological Surface Time Series Of The Greater Alpine Region (HISTALP) web site http://www.zamg. ac.at/histalp. The field measurements from 1982 to 2015 were supported by the Comitato Glaciologico Italiano. This work was partially funded by the Italian project of Interest NextData of the Italian Ministry for Education, University and Research.

We thank the scientific and associated chief editors, Carleen Tijm-Reijmer and Hester Jiskoot, the anonymous referee and Michael Kuhn for their efforts in reviewing the paper. David Winston revised the English in the manuscript.

\section{REFERENCES}

Bahr DB, Pfeffer WT, Sassolas C and Meier M (1998) Response time of glaciers as a function of size and mass balance: 1. Theory. J. Geophys. Res., 103, 9777-9782. (doi: 10.1029/98JB00507)

Carturan L and 11 others (2013a) Current behaviour and dynamics of the lowermost Italian glacier (Montasio Occidentale, Julian Alps), Geogr Ann Ser B Phys Geogr, 95 A, 79-96. (doi: 10.1111/geoa.12002).

Carturan L and 10 others (2013b) Area and volume loss of the glaciers in the Ortles-Cevedale group (Eastern Italian Alps): controls and imbalance of the remaining glaciers. Cryosphere, 7, 13391359. (doi: 10.5194/tc-7-1339-2013)

Chimani B and 12 others (2017) Klimaszenarien fur das Bundesland Tyrol bis 2100 FACTSHEET, version 1. Technical report, Wien, Austria.

Christian J, Koutnik M and Roe G (2018) Committed retreat: controls on glacier disequilibrium in a warming climate. J. Glaciol., 64, 675-688.

Citterio $M$ and 6 others (2007) The fluctuations of Italian glaciers during the last century: a contribution to knowledge about alpine glacier changes. Geogr. Ann. A, 89 A, 166-184 (doi: 10.1111/j.1468-0459.2007.00316.x).

Cogley J and 10 others (2011) Glossary of glacier mass balance and related terms, volume IACS Contribution No. 2. UNESCO-IHP, Paris.

Colucci RR (2016) Geomorphic influence on small glacier response to post-Little Ice Age climate warming: Julian Alps, Europe. Earth. Surf. Process. Landf., 41(9), 1227-1240. (doi: 10.1002/esp.3908)

Comitato Glaciologico Italiano (1981-2016) Relazioni delle campagne glaciologiche 1980-2015. Geogr. Fis. Din. Quat., 5-39.

Consiglio Nazionale delle Ricerche - Comitato Glaciologico Italiano (1959-1962) Catasto dei Ghiacciai Italiani. Anno Geofisico 1957-1958. Consiglio Nazionale delle RicercheComitato Glaciologico Italiano, Vol. 1-4. 
DeBeer CM and Sharp MJ (2009) Topographic influences on recent changes of very small glaciers in the Monashee Mountains, British Columbia, Canada. J. Glaciol., 55(192), 691-700. (doi: 10.3189/002214309789470851)

Diolaiuti G, Bocchiola D, Vagliasindi M, D'Agata C and Smiraglia C (2012) The 1975-2005 glacier change in Aosta Valley (Italy) and the relations with climate evolution. Prog. Phys. Geogr., 36, 764 785 (doi: 10.1177/0309133312456413).

Fischer A and 7 others (2018) Gletscher im Wandel: 125 jahre Gletschermessdienst des Alpenvereins. Berlin, Heidelberg: Springer Spektrum (doi: 10.1007/978-3-662-55540-8).

Giesen RH and Oerlemans J (2010) Response of the ice cap Hardangerjøkulen in southern Norway to the 20th and 21st century climates. Cryosphere, 4(2), 191 (doi: 10.5194/tc-4-1912010).

Gobiet Aand 5 others (2014) 21th century climate change in the European Alps - A review. Sci. Total Environ., 493, 11381151. (doi: 10.1016/j.scitotenv.2013.07.050)

Haeberli W, Hoelzle M, Paul F and Zemp M (2007) Integrated monitoring of mountain glaciers as key indicators of global climate change: the European Alps. Ann. Glaciol., 46, 150-160. (doi: 10.3189/172756407782871512)

Hoelzle M, Haeberli W, Dischl M and Peschke W (2003) Secular glacier mass balances derived from cumulative glacier length changes. Glob. Planet. Change, 36(4), 295-306.

Huss M and Fischer M (2016) Sensitivity of very small glaciers in the Swiss Alps to future climate change. Front. Earth Sci., 4(34), 117. (doi: 10.3389/feart.2016.00034)

IPCC (2014) Climate change 2014: synthesis report. In (Core Writing Team, Pachauri RK and Meyer LA eds. Contribution of working groups I, II and III to the Fifth Assessment Report of the Intergovernmental panel on climate change,vol. 151, IPCC, Geneva, Switzerland.

Leclercq PW and Oerlemans J (2012) Global and hemispheric temperature recontruction from glacier length fluctuations. Clim. Dyn., 38, 1065-1079. (doi: 10.1007/s00382-0111145-7)

Mackintosh AN, Dugmore AJ and Hubbard AL (2002) Holocene climatic changes in Iceland: evidence from modelling glacier length fluctuations at Sólheimajökull. Quat. Int., 91(1), 39-52. (doi: 10.1016/S1040-6182(01)00101-X)

Nakićenović $\mathrm{N}$ and 27 others (2000) A special report of working group III of the intergovernamental panel on climate change. Technical report, IPCC.

Nigrelli G, Lucchesi S, Bertotto S, Fioraso G and Chiarle M (2015) Climate variability and Alpine glaciers evolution in Northwestern Italy from the Little Ice Age to the 2010s. Theor. Appl. Climatol., 122(3-4), 595-608. (doi: 10.1007/s00704014-1313-x)

Oerlemans J (1994) Quantifying global warming from the retreat of glaciers. Science, 264, 243-245. (doi: 10.1126/science.264. 5156.243)

Oerlemans J (2005) Extracting a climate signal from 169 glacier records. Science, 308(675), 675-677.

Oerlemans J (2007) Estimating response times of Vadret da Morteratsch, Vadret da Palü, Bricksdalsbreen and Nigardsbreen from their length records. J. Glaciol., 53, 357-362. (doi: $10.3189 / 002214307783258387)$
Oerlemans J (2011) Minimal Glacier Models. Utrecht University, Utrecht, ISBN 78-90-6701-022-1.

Oerlemans J (2012) Linear modelling of glacier length fluctuations. Geogr. Ann. A, 94(2), 183-194. (doi: 10.1111/j.14680459.2012.00469.x)

Paul F, Kääb A, Maisch M, Kellenberger T and Haeberli W (2004) Rapid disintegration of Alpine glaciers observed with satellite data. Geophys. Res. Lett., 31(21), L21402, 1-4. (doi: 10.1029/ 2004GL020816)

Paul F, Machguth H and Kääb A (2005) On the impact of glacier albedo under conditions of extreme glacier melt: the summer of 2003 in the Alps. EARSeL eProceedings, 4(2), 139-149.

Paul F, Kääb A and Haeberli W (2007) Recent glacier changes in the Alps observed by satellite: consequences for future monitoring stategies. Glob. Planet. Change, 56, 111-122. (doi: 10.1016/j. gloplacha.2006.07.007)

Paul F and 9 others (2009) Recommendations for the compilation of glacier inventory data from digital sources. Ann. Glaciol., 50(53), 119-126. (doi: 10.3189/172756410790595778)

Paul F, Frey H and Le Bris R (2011) A new glacier inventory for the European Alps from Landsat TM scenes of 2003: challenges and results. Ann. Glaciol., 52, 144-152. (doi: 10.3189/ 172756411799096295)

Pfeffer WT, Sassolas C, Bahr DB and Meier M (1998) Response time of glaciers as a function of size and mass balance: 2. Numerical experiments. J. Geophys. Res., 103(B5), 1998 (doi: 10.1029/ 98JB00508)

Roe GH and O'Neal MA (2009) The response of glaciers to intrinsic climate variability: observations and models of late-Holocene variations in the Pacific Northwest. J. Glaciol., 55, 839-854. (doi: 10.3189/002214309790152438)

Serandrei-Barbero R and Zanon G (1993) Glaciers of the Alps: the Italian Alps. In Williams RS and Ferrigno JG eds. Satellite image atlas on glaciers of the world-Europe, 37-48, United States Geological Survey.

Serandrei-Barbero R, Rabagliati R, Binaghi E and Rampini A (1999) Glacial retreat in the 1980s in the Breonie, Aurine and Pusteresi groups (eastern Alps, Italy) in Landsat TM images. Hydrol. Sci. I. 44, 279-296. (doi: 10.1080/02626669909492222)

Smiraglia C and Diolaiuti G eds. (2015) The new Italian glacier inventory. Bergamo Pubbl., Bergamo.

Treyer A (2012) Die Gletscherentwicklung in der Durreckgruppe (Südtirol) seit dem Hochstand um 1850. Zeitschrift für Gletscherkunde und Glazialgeologie, 43/44, 213-230.

WGMS (2015) Fluctuations of Glaciers Database. World Glacier Monitoring Service, Zurich, Switzerland (doi: 10.5904/wgmsfog-2015-11).

Zecchetto S, Serandrei-Barbero R and Donnici S (2017) Temperature reconstruction from the length fluctuations of small glaciers in the eastern Alps (northeastern Italy). Clim. Dyn., 49(1-2), 363-374 (doi: 10.1007/s00382-016-3347-5).

Zemp $\mathrm{M}$ and 38 others (2015) Historically unprecedented global glacier decline in the early 21 st century. J. Glaciol., 61(228), 745-762. (doi: 10.3189/2015JoG15J017)

Zemp M, Hoelzle M and Haeberli W (2007) Distributed modelling of the regional climatic equilibrium line altitude of glaciers in the European Alps. Glob. Planet. Change, 56, 83-100. (doi: 10.1016/j.gloplacha.2006.07.002) 